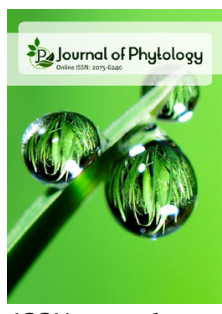

ISSN: $2075-6240$

\title{
Regeneration potential of different explants during micropropagation of neem tree (Azadirachta indica A. Juss.)
}

\author{
Bhavadharani Dhandapani', Gnanam Ramasamy ${ }^{2 *}$, Senthil Natesan², \\ Kumaran Kalyanasundaram ${ }^{3}$
}

'Department of Plant Biotechnology, Centre for Plant Molecular Biology \& Biotechnology, Tamil Nadu Agricultural University, Coimbatore-641003, Tamil Nadu, India, ${ }^{2}$ Department of Plant Molecular Biology and Bioinformatics, Centre for Plant Molecular Biology \& Biotechnology, Tamil Nadu Agricultural University, Coimbatore-641003, Tamil Nadu, India, ${ }^{3}$ Department of Forest Biology and Tree Improvement, Forest College and Research Institute, Tamil Nadu Agricultural University, Mettupalayam - 641 301, Tamil Nadu, India

\begin{abstract}
Azadirachta indica A. Juss., (Neem), a prodigious multipurpose tree, has immense potential to benefit mankind and to protect the environment. In order to investigate the effects of three different explants for its regeneration potential, de-embryonated cotyledon, immature zygotic embryo and nodal segments from a 30 year old neem plus tree were used. Half strength MS medium with benzyl amino purine $(3 \mathrm{mg} / \mathrm{L})$ and naphthalene acetic acid $(0.5 \mathrm{mg} / \mathrm{L})$ and casein hydrolysate $(1 \mathrm{~g} / \mathrm{L})$ was effective in shoot bud sprouting from both nodes and cotyledons. Half strength MS medium fortified with TDZ $(0.2 \mathrm{mg} / \mathrm{L})$ was effective for induction of somatic embryogenesis from zygotic embryos. Shoot buds initiated from the cotyledons produced a maximum number of shoots per explants (4) which on further sub culturing induced maximum multiple shoots (15) on half strength MS medium fortified with BAP (1.5 mg/L), NAA $(0.5 \mathrm{mg} / \mathrm{L})$ and $\mathrm{CH}(400 \mathrm{~g} / \mathrm{L})$ and the nodal explants induced only 4-5 axillary shoots on further sub culturing. Even though immature zygotic embryos produced more number of somatic embryos per explant (25) within a short time (30-45 days), the plantlet conversion was poor $(25.52 \%)$. In vitro rooting was observed in half strength MS medium supplemented with IBA $(2 \mathrm{mg} / \mathrm{L})$. The regeneration potential of de-embryonated cotyledons through a simple regeneration system may be beneficial for efficient mass propagation of selected plus trees of neem.
\end{abstract}

Revised: August 28, 2021

Accepted: November 23, 2021

Published: December 17, 2021

*Corresponding Author:

Gnanam Ramasamy,

E-mail: gnanam.r@tnau.ac.in

KEYWORDS: Azadirachta indica, immature zygotic embryo, nodal explants, de-embryonated cotyledons

\section{INTRODUCTION}

Neem (Azadirachta indica A. Juss.,) is a versatile tree used for urban re-greening, agroforestry systems, fuel and wood production, as well as for a number of additional benefits such as bio pesticides. It belongs to the family Meliaceae and is believed to be originated from Southeast Asia and distributed through tropical and subtropical regions of the world. Neem tree has numerous medicinal, agrochemical and economic uses to its credit. The leaves, bark and seeds are used for multiple purposes owing to its medicinal properties (Gehlot et al., 2014). Neem seed kernel has several bioactive compounds which is responsible for larvicidal, antifeedant and insect repellent properties. The medicinal and biopesticidal properties of neem are mainly attributed to the presence of a mixture of limonoids (Chaturvedi et al., 2004a). Around 150 structurally complex and chemically diverse active substances have been extracted from neem leaves, fruits and stems including terpenoids, limonoids, sulfurous compounds, polyphenolics, dihydrochalcones, coumarin and aliphatic compounds (Subapriya \& Nagini, 2005). Neem oil, seed cake, and bark from the tree have potential value in the global market. The tree yields an average of $37-50 \mathrm{~kg}$ of fresh fruits every year. The kernel yields roughly $45 \%$ of neem oil and $55 \%$ of neem cake. The reproductive phase usually begins after 5 years. Neem fruit is available from June-August that coincides with the rainy season in India. Due to operational issues and quality concerns, only about one-third of the fruits are harvested. Traditionally, neem is propagated through seeds. As the seeds are recalcitrant in nature and rapidly loses viability, it limits the storage and distant distribution of propagules (Murthy \& Saxena, 1998; Deb, 2001). This restricts seed distribution and storage for year-round propagules availability. Due to cross-pollination, seed propagation also has the drawback of heterogeneity (Srivastava \& Chaturvedi, 2018). Numerous tissue culture techniques have been developed to achieve rapid clonal propagation system of high azadirachtin genotypes over 
seed propagation that helps in year round multiplication of elite trees. Several workers have reported in vitro culture studies in neem. Axillary shoot proliferation from different explants including nodal segments (Thengane et al., 1995; Quraishi et al., 2004; Chaturvedi et al., 2004a; Srinidhi et al., 2008; Arora et al., 2010), apical and axillary shoot buds (Quraishi et al., 2004) were reported. For the induction of adventitious shoot proliferation, leaf tip (Salvi et al., 2001), leaf discs (Arora et al., 2010), zygotic embryo (Rangaswamy \& Promila, 1972; Chaturvedi et al., 2004a) were used as explants. Somatic embryogenesis is the method of choice among many in vitro procedures, as it offers several advantages, including the option of converting regenerants to artificial or synthetic seeds, as well as a single-cell origin for the regenerants. Several explants including cotyledons (Shrikhande et al., 1993; Murthy \& Saxena, 1998), hypocotyl (Su et al., 1997), immature zygotic embryos (Chaturvedi et al., 2004b; Rout, 2005) and leaflets (Akula et al., 2003; Shekhawat et al., 2009) were used in the induction of somatic embryogenesis. With this background, the current study assessed the potential of three different explants on plant regeneration potential during neem micropropagation.

\section{MATERIALS AND METHODS}

\section{Plant Material and Initiation of Aseptic Cultures}

Green immature pods (50 days after anthesis) and single nodal cuttings $(5 \mathrm{~cm})$ were collected from a 30 year old neem plus trees growing in the Tamil Nadu Agricultural University, Coimbatore $\left(11.0122^{\circ} \mathrm{N}, 76.9354^{\circ} \mathrm{E}\right)$. Freshly collected green pods were washed thoroughly with running tap water, the endocarp was removed and the seed coat was peeled out without damaging the cotyledon. The cotyledon was split into two and the embryo was collected separately. The de-embryonated cotyledon and the immature zygotic embryo were used as explants. For preparation of nodal explants, the leaves were trimmed off and single nodal explants $(3 \mathrm{~cm})$ were used. The single nodes and de-embryonated cotyledons were pre washed in 1-2 drops tween 20 in distilled water along with 0.1 per cent bavistin for 20 minutes. A quick $(30 \mathrm{sec})$ rinse in 70 per cent ethanol followed by $\mathrm{HgCl}_{2}(0.1 \%)$ for $8 \mathrm{~min}$ and five rinses with sterile water was given in the laminar air flow chamber just before inoculation. The immature zygotic embryos were surface sterilized with $\mathrm{HgCl}_{2}, 0.1 \%$ ) for $3 \mathrm{~min}$. followed by five rinses with sterile water. The nodal cuttings were slightly trimmed at both ends to expose fresh tissue before inoculation whereas the cotyledon was placed facing the ventral side (flat surface) down to the medium. Full and half strength MS medium supplemented with casein hydrolysate (CH, 1 g/l), sucrose (3\%) and 6- benzyl amino purine (BAP, $3.0 \mathrm{mg} / \mathrm{L}$ ) or kinetin $(3.0 \mathrm{mg} / \mathrm{L})$ either alone or in combination with 1- naphthalene acetic acid (NAA, $0.5 \mathrm{mg} / \mathrm{L}$ ) was used for induction of axillary and adventitious shoots from nodal and cotyledon explants respectively. The excised immature zygotic embryos were inoculated in half or full strength MS medium at two different levels of BAP $(2,03.0 \mathrm{mg} / \mathrm{L})$ in combination with NAA $(0.5 \mathrm{mg} / \mathrm{L})$ or TDZ at two levels $(0.2$ and $0.4 \mathrm{mg} / \mathrm{L})$. The $\mathrm{pH}$ of the medium was adjusted to 5.7 with $0.1 \mathrm{~N} \mathrm{NaOH}$ or $\mathrm{HCl}$ before adding agar $(8 \mathrm{~g} / \mathrm{L})$. The nutrient medium was autoclaved for $20 \mathrm{~min}$ at $121^{\circ} \mathrm{C}$ at 15 psi pressure and dispensed in sterile test tubes/bottles/petri dishes in the laminar flow. The de-embryonated cotyledon and the immature zygotic embryos were kept in dark for 7 days and later incubated in 16/8 hrs light/ dark photoperiod whereas the nodal cultures were incubated continuously 16/8 hrs light/dark cycle with a light intensity of $50 \mu \mathrm{mol} \mathrm{m} \mathrm{m}^{-2} \mathrm{~s}^{-1}$ provided by cool white fluorescence lamps at $25 \pm 2^{\circ} \mathrm{C}$.

\section{Induction of Organogenesis and Somatic Embryogenesis}

At the end of bud break ( 15 days after inoculation), the shoots got initiated in the induction medium (full and half strength MS fortified with $\mathrm{CH}(1 \mathrm{~g} / \mathrm{L})$, BAP or kinetin with or without NAA was sub cultured into same medium and later small individual shoots $(2.0 \mathrm{~cm})$ from 5 -week old cultures were excised carefully and sub cultured into half strength MS medium supplemented with BAP $(1.5 \mathrm{mg} / \mathrm{L})+\mathrm{NAA}(0.5 \mathrm{mg} / \mathrm{L})+\mathrm{CH}(400 \mathrm{mg} / \mathrm{L})$ for shoot proliferation and elongation. For in vitro rooting, elongated shoots $(4-5 \mathrm{~cm})$ were excised and cultured on half strength MS medium supplemented with indole-3-butyric acid $(3 \mathrm{mg} / \mathrm{L})$ and activated charcoal $(200 \mathrm{mg} / \mathrm{L})$. Observations on percentage of bud break/establishment $(\%)$ days required for shoot initiation and number of shoots per explants were made. In case of zygotic embryos, pro embryogenic masses (PEMs) induced were transferred to a fresh medium of same combination and early stage embryos got induced and later asynchronous development lead to further stages of embryos including cotyledonary stage embryos which were sub cultured for plant conversion in half strength MS fortified with TDZ $(0.1 \mathrm{mg} / \mathrm{L})$. Observations on response to PEM induction $(\%)$ number of somatic embryos/explant and plant conversion percent $(\%)$ were documented. Each treatment was replicated three times with 20 explants per replication.

\section{Acclimatization and Transfer to Greenhouse Condition}

Well rooted plants with 5-7 leaves were removed from culture vessels, washed gently under sterile water to remove the agar and dipped in bavistin $(0.1 \%)$ and transferred to small paper cups containing a mixture of sand: soil: vermiculite in the ratio of 1:1:1 and were covered with transparent sheets for 10 days. Later well-established plants were transferred to polybags and maintained in the greenhouse for further acclimatization.

\section{Statistical Analysis}

The experiment was done in completely randomized design with three replications. The data were analyzed by one way ANOVA using WASP 2.0 (Web Agri Stat Package) and means were compared by Duncan's Multiple Range Test in OPSTAT online software.

\section{RESULTS AND DISCUSSION}

Nodal segments and de-embryonated cotyledons showed direct organogenesis and shoot initiation occurred. The nodal segments were mostly contaminated with fungus and rarely 
by bacteria when explants were collected during December to February. The flowering starts from the month of March in India and cotyledons and nodal segments inoculated during March to May exhibited less contamination. So, the contamination level might be related to collection of explants during the rainy season (Dec-Feb) and a similar seasonal effects in neem have earlier been reported in previous studies (Chaturvedi et al., 2004a).

\section{Effect of Different Explants and Medium Combinations on Shoot Induction}

Direct shoot organogenesis of neem from the two different explants (node and de-embryonated cotyledon) on different medium combinations were studied and presented in Table 1. There is a difference in origin of shoots with the respect to the explants. From nodes, after an initial bud break, axillary shoot induction occurred whereas after bulging of explants, adventitious shoots were induced from cotyledons in MS medium fortified with $\mathrm{CH}(\mathrm{lg} / \mathrm{L})$, BAP or Kinetin with or without NAA. De-embryonated cotyledon was selected as explant based on several previous reports in oilseeds including Sesamum indicum (Chowdhury et al., 2014), where deembryonated cotyledons were the preferred explants due to less time of regeneration (within 2 weeks). In tree species including Sesbania grandiflora (Detrez et al., 1994) and Albizzia falcataria (Sinha \& Mallick, 1993), cotyledonary segments were suggested as suitable explants for in vitro regeneration. A significant difference between the two explants in response to percentage of establishment, days required for shoot initiation and number of shoots per explants was observed for a given set of phytohormones supplemented in the medium. Bud break in the nodal segments was observed on 10-15 days after inoculation and axillary shoots emerged on $26^{\text {th }}$ day (Figure la-c). The de-embryonated cotyledons bulged after 7 days of inoculation and shoot initiation was observed 30 days after inoculation (Figure 2a-c). Callusing was observed at the basal end of the nodal segments (Figure ld) and de-embryonated cotyledons in the full strength MS medium that inhibited further induction of the axillary and adventitious shoots which was significantly reduced in the half strength MS medium. These observations were in accordance with (Rout, 2005; Srinidhi et al., 2008). The percentage of establishment recorded in nodal explants was 39.30 to 46.87 in case of half strength MS medium with a maximum response in $1 / 2$ MS supplemented with BAP $(3.0 \mathrm{mg} / \mathrm{L})$ and NAA $(0.5 \mathrm{mg} / \mathrm{L})$ along with $\mathrm{CH}(1 \mathrm{~g} / \mathrm{L})$ whereas full strength MS medium recorded 29.67 to 36.23 per cent. In de-embryonated cotyledon, the full strength MS with BAP or Kinetin at $3 \mathrm{mg} / \mathrm{L}$ with or without NAA $(0.5 \mathrm{mg} / \mathrm{L})$ and $\mathrm{CH}$ $(1 \mathrm{~g} / \mathrm{L})$ recorded 33.33-38.00 per cent bud break whereas in half strength it was 42.91-49.67 per cent. Maximum bud break (46.87 and 49.67\%) was documented in half strength MS with BAP $(3.0 \mathrm{mg} / \mathrm{L})$ and NAA $(0.5 \mathrm{mg} / \mathrm{L})$ and $\mathrm{CH}(1 \mathrm{~g} / \mathrm{L})$ containing medium than that of Kinetin $(3.0 \mathrm{mg} / \mathrm{L})$ with same level of NAA $(0.5 \mathrm{mg} / \mathrm{L})$ and $\mathrm{CH}(1 \mathrm{~g} / \mathrm{L})$ in nodes and cotyledons respectively. Basal full strength MS medium recorded the lowest bud break $(10.4$ and $11 \%)$ in nodes and cotyledons respectively.

The days taken for first initiation of shoots were lowest viz., 26 and 27.50 from nodes and de-embryonated cotyledons respectively in $1 / 2$ MS medium supplemented with BAP $(3.0 \mathrm{mg} / \mathrm{L})$ and NAA $(0.5 \mathrm{mg} / \mathrm{L})$ along with CH $(1 \mathrm{~g} / \mathrm{L})$. In case of nodes, shoot initiation took a maximum 45.33, 32.47 and 31 days in basal, full and half strength MS medium respectively. In case of cotyledons, shoot initiation was noticed in 42, 30 and 27.5 days in basal, full and half strength MS medium respectively. A maximum number of 3.00 and 4.33 shoots were induced from nodes and cotyledons respectively in half strength MS medium fortified with BAP $(3.0 \mathrm{mg} / \mathrm{l})$ alone along with CH $(1 \mathrm{~g} / \mathrm{L})$ and

Table 1: Effect of strength of MS medium (full and half) and growth regulators on bud sprouting and shoot regeneration from nodal explants and de-embryonated cotyledons

\begin{tabular}{|c|c|c|c|c|c|c|c|c|c|c|c|}
\hline \multirow[t]{2}{*}{ S.No } & \multirow[t]{2}{*}{ Treatment } & \multirow[t]{2}{*}{ MS } & \multirow[t]{2}{*}{$\begin{array}{c}\mathrm{BA} \\
(\mathrm{mg} / \mathrm{l})\end{array}$} & \multirow[t]{2}{*}{$\begin{array}{c}\mathrm{KN} \\
(\mathrm{mg} / \mathrm{l})\end{array}$} & \multirow[t]{2}{*}{$\begin{array}{l}\text { NAA } \\
(\mathrm{mg} / \mathrm{l})\end{array}$} & \multicolumn{2}{|c|}{$\begin{array}{c}\text { Bud break / Percentage of } \\
\text { establishment }\end{array}$} & \multicolumn{2}{|c|}{$\begin{array}{l}\text { Days required for shoot } \\
\text { initiation }\end{array}$} & \multicolumn{2}{|c|}{ No. of shoots/explant } \\
\hline & & & & & & Node & Cotyledon & Node & Cotyledon & Node & Cotyledon \\
\hline 1 & T0 & $\begin{array}{l}\text { Full } \\
\text { strength }\end{array}$ & - & - & - & $\begin{array}{c}10.40 \\
(18.80 \pm 0.61)^{g}\end{array}$ & $\begin{array}{c}11.0 \\
(19.32 \pm 1.06)^{\mathrm{e}}\end{array}$ & $45.33 \pm 4.06^{a}$ & $42.33 \pm 2.40^{a}$ & $\begin{array}{c}0.67 \\
(1.05 \pm 0.17)^{c}\end{array}$ & $\begin{array}{c}1.00 \\
(1.00 \pm 0.0)^{c}\end{array}$ \\
\hline 2 & $\mathrm{~T} 1$ & $\begin{array}{l}\text { Full } \\
\text { strength }\end{array}$ & 3.0 & - & 0.5 & $\begin{array}{c}29.67 \\
(32.96 \pm 0.45)^{f}\end{array}$ & $\begin{array}{c}36.0 \\
(36.83 \pm 1.84)^{\mathrm{cd}}\end{array}$ & $29.67 \pm 2.73^{b c}$ & $31.66 \pm 0.88^{\mathrm{bcd}}$ & $\begin{array}{c}1.88 \\
(1.54 \pm 0.01)^{\mathrm{ab}}\end{array}$ & $\begin{array}{c}3.33 \\
(1.82 \pm 0.09)^{\mathrm{ab}}\end{array}$ \\
\hline 3 & $\mathrm{~T} 2$ & $\begin{array}{l}\text { Full } \\
\text { strength }\end{array}$ & 3.0 & - & - & $\begin{array}{c}36.23 \\
(37.00 \pm 0.77)^{\mathrm{cd}}\end{array}$ & $\begin{array}{c}38.0 \\
(38.03 \pm 1.71)^{\mathrm{bcd}}\end{array}$ & $32.33 \pm 0.88^{b}$ & $31.33 \pm 1.86^{\mathrm{bcd}}$ & $\begin{array}{c}2.47 \\
(1.72 \pm 0.03)^{a b}\end{array}$ & $\begin{array}{c}3.00 \\
(1.71 \pm 0.17)^{\mathrm{ab}}\end{array}$ \\
\hline 4 & T3 & $\begin{array}{l}\text { Full } \\
\text { strength }\end{array}$ & - & 3.0 & 0.5 & $\begin{array}{c}30.80 \\
(33.70 \pm 0.59)^{\text {ef }}\end{array}$ & $\begin{array}{c}33.33 \\
(35.25 \pm 1.08)^{d}\end{array}$ & $31.00 \pm 1.53^{b c}$ & $30.66 \pm 2.03^{c d}$ & $\begin{array}{c}2.43 \\
(1.71 \pm 0.05)^{\mathrm{ab}}\end{array}$ & $\begin{array}{c}3.67 \\
(1.88 \pm 0.24)^{\mathrm{ab}}\end{array}$ \\
\hline 5 & T4 & $\begin{array}{l}\text { Full } \\
\text { strength }\end{array}$ & - & 3.0 & - & $\begin{array}{c}33.33 \\
(35.26 \pm 0.99)^{\mathrm{de}}\end{array}$ & $\begin{array}{c}38.0 \\
(38.01 \pm 2.10)^{\mathrm{bcd}}\end{array}$ & $32.47 \pm 0.87^{b}$ & $32.00 \pm 2.08^{\mathrm{bcd}}$ & $\begin{array}{c}1.86 \\
(1.53 \pm 0.04)^{\mathrm{ab}}\end{array}$ & $\begin{array}{c}3.33 \\
(1.79 \pm 0.24)^{\mathrm{ab}}\end{array}$ \\
\hline 6 & $\mathrm{~T} 5$ & $\begin{array}{l}\text { Half } \\
\text { strength }\end{array}$ & 3.0 & - & 0.5 & $\begin{array}{c}46.87 \\
(43.2 \pm 0.58)^{\mathrm{a}}\end{array}$ & $\begin{array}{c}49.67 \\
(44.81 \pm 1.16)^{a}\end{array}$ & $26.00 \pm 1.53^{c}$ & $27.50 \pm 0.87^{d}$ & $\begin{array}{c}2.38 \\
(1.69 \pm 0.08)^{\mathrm{ab}}\end{array}$ & $\begin{array}{c}3.67 \\
(1.91 \pm 0.09)^{\mathrm{ab}}\end{array}$ \\
\hline 7 & T6 & $\begin{array}{l}\text { Half } \\
\text { strength }\end{array}$ & 3.0 & - & - & $\begin{array}{c}41.95 \\
(40.36 \pm 0.50)^{b}\end{array}$ & $\begin{array}{c}44.79 \\
(41.93 \pm 1.02)^{a b}\end{array}$ & $30.33 \pm 0.1 .45^{b c}$ & $33.00 \pm 2.31^{b c}$ & $\begin{array}{c}3.00 \\
(1.85 \pm 0.15)^{\mathrm{a}}\end{array}$ & $\begin{array}{c}4.33 \\
(2.08 \pm 0.08)^{a}\end{array}$ \\
\hline 8 & T7 & $\begin{array}{l}\text { Half } \\
\text { strength }\end{array}$ & - & 3.0 & 0.5 & $\begin{array}{c}42.63 \\
(40.73 \pm 0.72)^{b}\end{array}$ & $\begin{array}{c}45.34 \\
(42.51 \pm 1.01)^{\mathrm{ab}}\end{array}$ & $28.00 \pm 1.53^{b c}$ & $29.33 \pm 0.88^{c d}$ & $\begin{array}{c}2.33 \\
(1.67 \pm 0.09)^{\mathrm{ab}}\end{array}$ & $\begin{array}{c}4.00 \\
(1.99 \pm 0.15)^{\mathrm{ab}}\end{array}$ \\
\hline 9 & T8 & $\begin{array}{l}\text { Half } \\
\text { strength }\end{array}$ & - & 3.0 & - & $\begin{array}{c}39.30 \\
(38.83 \pm 0.58)^{b c}\end{array}$ & $\begin{array}{c}42.91 \\
(40.77 \pm 1.40)^{a b c}\end{array}$ & $31.00 \pm 1.53^{b c}$ & $36.00 \pm 1.53^{b}$ & $\begin{array}{c}1.67 \\
(1.43 \pm 0.21)^{b c}\end{array}$ & $\begin{array}{c}2.67 \\
(1.62 \pm 0.11)^{b}\end{array}$ \\
\hline
\end{tabular}

Treatments found to be significant at $5 \%$ level of significance; Means were compared by Duncan's Multiple Range Test; Values in the parentheses of percentage of establishment are arc sine transformed and Values in the parentheses of number of shoots per explant are square root transformed mean \pm standard error 

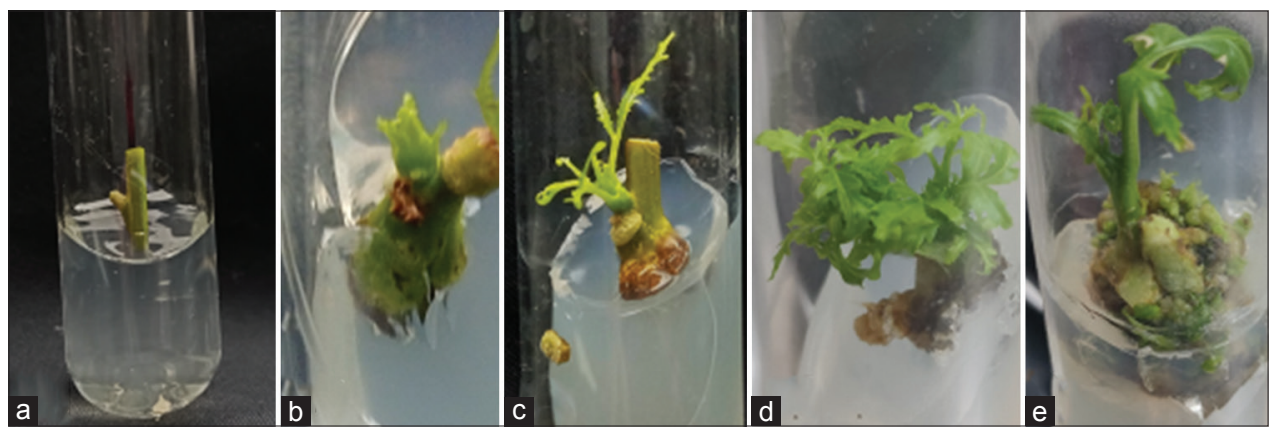

Figure 1: Axillary shoot proliferation through node culture. (a) Single nodal cuttings, (b) Bud break at the nodal region15 DAI, (c) Shoot induction from nodes 26 DAI, (d) Multiple shoots from node $45 \mathrm{DAl}$, (e) Basal callusing in full strength MS medium
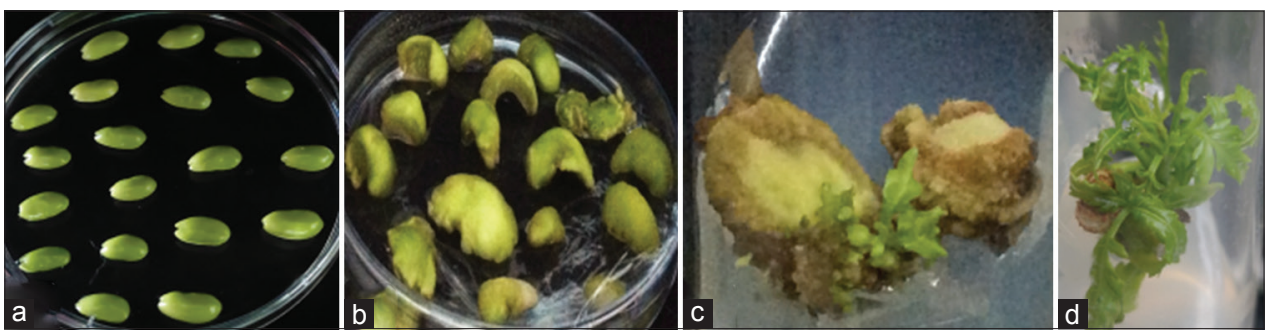

Figure 2: Adventitious shoot induction from de-embryonated cotyledons. (a) De-embryonated cotyledons, (b) Bulged and swollen explants 7 DAI, (c) Shoots induction on the cotyledon $30 \mathrm{DAl}$, (d) Multiple shoot induction

addition of NAA actually reduced the number of shoots. Basal medium could retain the single shoot induced during the bud break and a similar findings have been reported by (Srinidhi et al., 2008). Among the cytokinins, BAP was found to be better than Kinetin for higher bud break, minimum number of days for shoot initiation and more number of shoots both in nodes and cotyledons (Table 1) whereas Thengane et al. (1995) documented that MS medium supplemented with both BAP and Kinetin was efficient for sprouting. Houllou et al. (2015) earlier reported that development of shoot tips from embryo with cotyledons were significantly higher than embryo without cotyledon and suggested that cotyledons are essential for the better shoot tip proliferation. However, current study revealed that de-embryonated cotyledon showed a maximum bud break $(44.79 \%)$ with a maximum of 4.0 shoots in 27.50 days as against $41.95 \%$ bud break with 3.00 shoots in 26 days in nodes.

\section{Somatic Embryogenesis}

Immature zygotic embryos were efficiently used in other plants to obtain somatic embryogenesis, such as Castanea sativa Mill. (Sezgin \& Dumanoglu, 2014), Fraxinus mandshurica Rupr. (Kong et al., 2012), Acacia senegal (L.) Willd. (Rathore et al., 2012), Cassia angustifolia (Parveen \& Shahzad, 2014). These explants are more proficient for somatic embryo induction, metabolically and biochemically, due to presence of milky white content in immature cotyledons of neem (Gairi \& Rashid, 2005). Recalcitrant species including cereals, pines and cotton, immature zygotic embryos are the most suitable explants for establishing regenerating cultures due to their juvenile nature. Immature zygotic embryos were found to be the best starting material for induction of somatic embryogenesis in several perennial crops (Chaturvedi et al.,
2004). In spite of having such valued properties, improvement of neem by conventional methods is very limited owing to its highly heterozygous nature, long reproductive cycle and poor seed yield and somatic embryogenesis may offer an effective system for plant regeneration (Singh and Chaturvedi, 2009) with a maximum embryogenic response in least number of days directly (Chaturvedi et al., 2004). In this study, induction of somatic embryogenesis was achieved directly without any callus formation from immature zygotic embryos collected from unripe fruits 50 day after anthesis on full and half strength MS medium fortified with BAP ( 2 and $3 \mathrm{mg} / \mathrm{L}$ ) along with NAA $(0.5 \mathrm{mg} / \mathrm{L})$ or TDZ $(0.2$ and $0.4 \mathrm{mg} / \mathrm{L})$ along with CH $(1 \mathrm{~g} / \mathrm{L})$ and the results are presented in Table 2., Observation made during embryogenesis experiments were response to PEM induction(\%), number of somatic embryos per explant and plantlet conversion ratio from somatic embryos. After inoculation, within 15 days, a pale green, glossy pro-embryogenic mass (PEM) was observed (Figure 3). A maximum number of embryos responded in full and half strength MS medium supplemented with TDZ $(0.2 \mathrm{mg} / \mathrm{L})$. After 15 days, PEMs were transferred to a fresh medium of same combination. On $30^{\text {th }}$ day, early stage embryos were induced and on $45^{\text {th }}$ day, all stages of embryos could be seen confirming asynchronous nature of somatic embryogenesis (Figure 4$)$. The combination of BAP (2 and $3 \mathrm{mg} / \mathrm{L})$ along with NAA $(0.5 \mathrm{mg} / \mathrm{L})$ and $\mathrm{CH}(\mathrm{lg} / \mathrm{L})$ could initiate a proembryonic response of 22.99, 26.78 and 20.87, $27.30 \%$ in full and half strength MS medium respectively. Deb (2001) induced somatic embryogenesis using cotyledons and mentioned that NAA was effective for the induction of somatic embryogenesis, while, Rout, (2005) observed BAP along with 2,4-D showed high proliferation and suggested that the high concentration of NAA $(>8.05 \mu \mathrm{M})$ leads to browning of calli. Casein hydrolysate acted as a key element in the induction 
Table 2: Effect of different concentrations and combinations of growth regulators on the frequency of somatic embryo formation and conversion into plantlets

\begin{tabular}{|c|c|c|c|c|c|c|c|c|}
\hline S.no & Treatment & MS & $\mathrm{BA}(\mathrm{mg} / \mathrm{l})$ & NAA (mg/l) & TDZ (mg/l) & $\begin{array}{l}\text { Response to PEM } \\
\text { induction (\%) }\end{array}$ & $\begin{array}{l}\text { No. of somatic } \\
\text { embryos/explant }\end{array}$ & $\begin{array}{l}\text { Conversion } \\
\text { percent (\%) }\end{array}$ \\
\hline 1 & T0 & Full strength & - & - & - & & $\begin{array}{c}0.00 \\
(0.71 \pm 0.00)^{9}\end{array}$ & $\begin{array}{c}0.00 \\
(0.00 \pm 0.00)^{\mathrm{e}}\end{array}$ \\
\hline 2 & $\mathrm{~T} 1$ & Full strength & 2.0 & 0.5 & - & $\begin{array}{c}22.99 \\
(28.62 \pm 1.10)^{\mathrm{ef}}\end{array}$ & $\begin{array}{c}9.21 \\
(3.11 \pm 0.12)^{f}\end{array}$ & $\begin{array}{c}14.44 \\
(22.26 \pm 1.46)^{c d}\end{array}$ \\
\hline 3 & T2 & Full strength & 3.0 & 0.5 & - & $\begin{array}{c}26.78 \\
(31.15 \pm 0.80)^{\mathrm{de}}\end{array}$ & $\begin{array}{c}10.38 \\
(3.29 \pm 0.12)^{\mathrm{ef}}\end{array}$ & $\begin{array}{c}12.08 \\
(20.31 \pm 0.78)^{d}\end{array}$ \\
\hline 4 & T3 & Full strength & - & - & 0.2 & $\begin{array}{c}35.13 \\
(36.34 \pm 1.07)^{\mathrm{a}}\end{array}$ & $\begin{array}{c}21.88 \\
(4.72 \pm 0.25)^{\mathrm{ab}}\end{array}$ & $\begin{array}{c}21.76 \\
(27.78 \pm 0.95)^{\mathrm{ab}}\end{array}$ \\
\hline 5 & T4 & Full strength & - & - & 0.4 & $\begin{array}{c}31.48 \\
(34.12 \pm 0.91)^{\mathrm{abc}}\end{array}$ & $\begin{array}{c}16.78 \\
(4.14 \pm 0.23)^{c d}\end{array}$ & $\begin{array}{c}17.32 \\
(24.54 \pm 1.34)^{b c}\end{array}$ \\
\hline 6 & T5 & Half strength & 2.0 & 0.5 & - & $\begin{array}{c}20.87 \\
(27.16 \pm 0.94)^{f}\end{array}$ & $\begin{array}{c}13.21 \\
(3.70 \pm 0.15)^{\mathrm{de}}\end{array}$ & $\begin{array}{c}13.48 \\
(21.41 \pm 1.80)^{\text {cd }}\end{array}$ \\
\hline 7 & T6 & Half strength & 3.0 & 0.5 & - & $\begin{array}{c}27.30 \\
(31.48 \pm 0.98)^{\mathrm{cd}}\end{array}$ & $\begin{array}{c}12.06 \\
(3.44 \pm 0.13)^{\text {ef }}\end{array}$ & $\begin{array}{c}21.76 \\
(27.79 \pm 0.97)^{\mathrm{ab}}\end{array}$ \\
\hline 8 & $\mathrm{~T} 7$ & Half strength & - & - & 0.2 & $\begin{array}{c}32.20 \\
(34.57 \pm 0.78)^{\mathrm{ab}}\end{array}$ & $\begin{array}{c}24.97 \\
(5.05 \pm 0.08)^{\mathrm{a}}\end{array}$ & $\begin{array}{c}25.52 \\
(30.31 \pm 1.19)^{a}\end{array}$ \\
\hline 9 & T8 & Half strength & - & - & 0.4 & $\begin{array}{c}29.67 \\
(32.99 \pm 1.10)^{\mathrm{bcd}}\end{array}$ & $\begin{array}{c}19.43 \\
(4.45 \pm 0.24)^{b c}\end{array}$ & $\begin{array}{c}19.28 \\
(26.02 \pm 0.97)^{b}\end{array}$ \\
\hline
\end{tabular}

Treatments found to be significant at $5 \%$ level of significance; Means were compared by Duncan's Multiple Range Test; Values in the parentheses for percent response and conversion ratio are the arc sine transformed. Values in the parentheses for no.of somatic embryos per explant are square root transformed mean \pm standard error
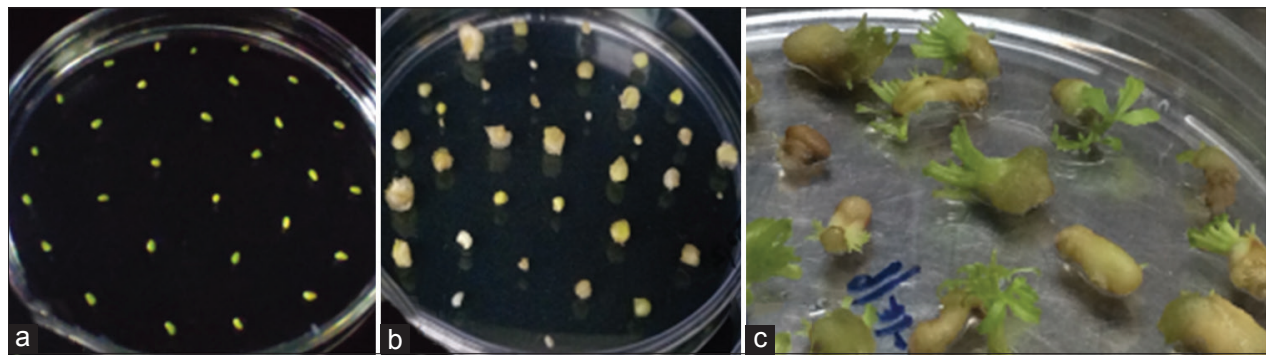

Figure 3: Somatic embryo induction from immature zygotic embryos. (a) Immature zygotic embryo, (b) Proembryonic mass 15 DAl, (c) Induction of somatic embryo after $30 \mathrm{DAl}$
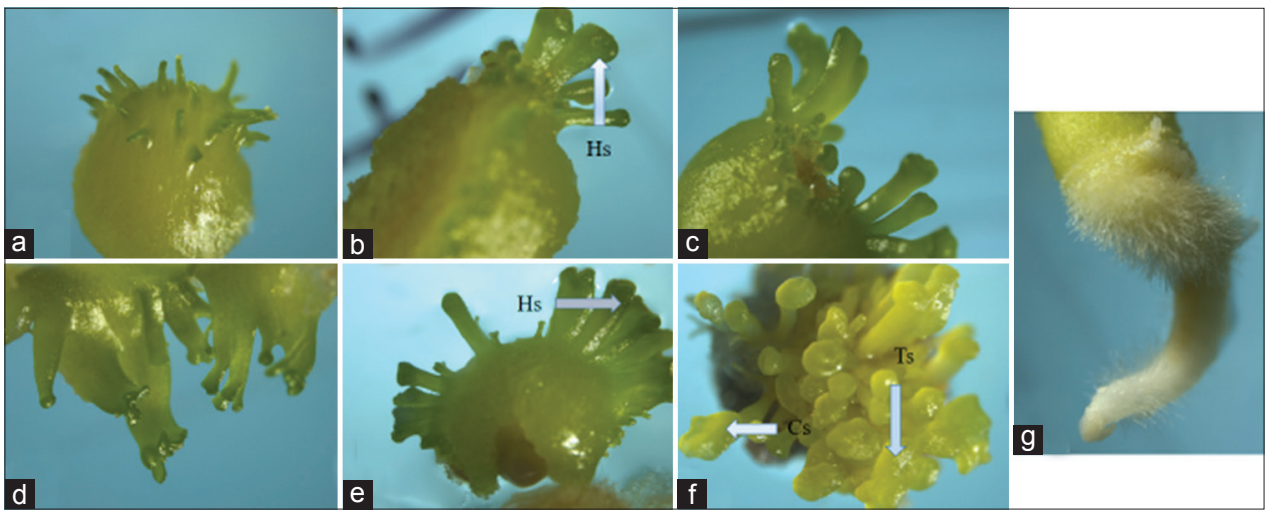

Figure 4: Development stages of somatic embryos (SEs) on immature zygotic embryo. (a-f). Asynchrous development of SEs on explants with embryos in heart (Hs), torpedo (Ts) and cotyledonary stage (Cs), 4(g). Root regeneration monopolar structure from embryo

of somatic embryogenesis. The present study revealed that low concentration of TDZ $(0.2 \mathrm{mg} / \mathrm{L})$ was effective in the induction of maximum proembryonic mass $(32.20 \%)$ with 24.97 embryos induced/explant with a maximum plant conversion of $25.52 \%$ only in half strength MS medium of same combination. Though PEM induction was higher (35.13\%) in full strength, no of embryos (21.88) and plant conversion (21.76\%) remained lower. Low concentrations of TDZ was also suggested by
Murthy \& Saxena, (1998) who worked on induction of direct and indirect somatic embryogenesis in neem. Somatic embryos are required to produce bipolar structures. But in case of neem, many of embryos were found to produce either shoot or root as monopolar structure. It was difficult to identify the bipolar structure. Even with a maximum number of 24.97 embryos induced, only 25.52 per cent of them could be converted into whole plants (Table 2). The same issue was reported in previous 


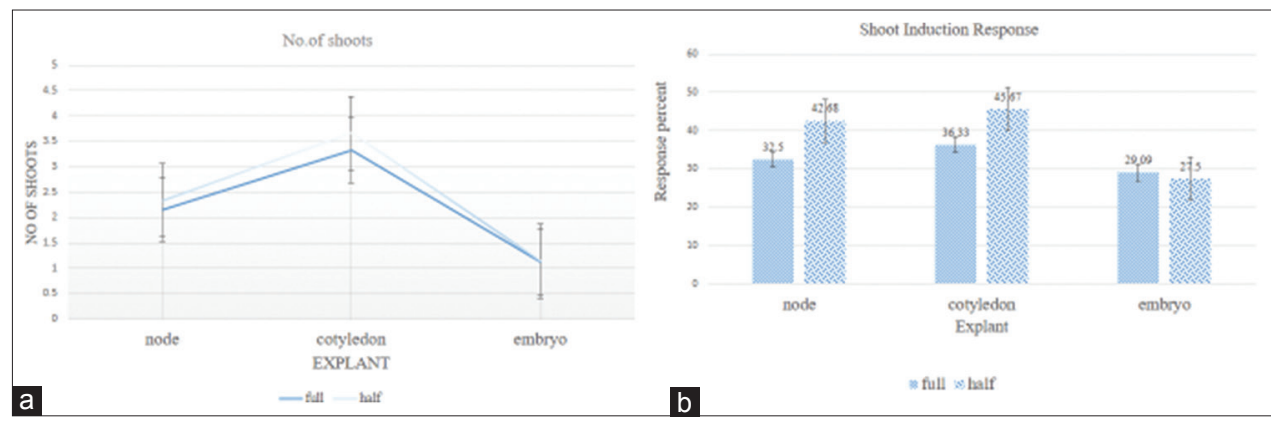

Figure 5: (a) Graphical representation of no. of shoot development from different explant on full and half strength MS media, (b).shoot response percentage from different explants on full and half strength MS media

findings where, only shoot region were observed as monopolar structure from embryos (Shrikhande et al., 1993; Su et al., 1997) and only root region (Chaturvedi et al., 2004b). This could be due to the poorly developed vascular strands at the radicular and plumular axes, that resulted in the loss of connection between the two poles all along the length of somatic embryos and, thus, hampering the bipolar germination. Such kind of low conversion was encountered by Srivastava \& Chaturvedi, (2018), who mentioned that the maturation of somatic embryos has always been a problem in neem. Among the three explants used, cotyledon showed maximum response and more number of shoots and half strength MS medium performed better than full strength MS medium (Figure 5).

The somatic embryos were sub cultured 45 days after inoculation for plantlet conversion on the nutrient media supplemented with reduced concentration of TDZ $(0.1 \mathrm{mg} / \mathrm{L})$ and casein hydrolysate (400 mg/L) (Murthy and Saxena, 1998). The conversion ratio of somatic embryos to plantlets was found to be low (maximum 25.52\%) suggesting more basic research is required to understand factors affecting induction and regeneration of somatic embryos.

\section{Shoot Proliferation and Rooting}

The shoots induced from cotyledons were further sub cultured on $45^{\text {th }}$ day after inoculation to $1 / 2$ MS medium fortified with BAP $(1.5 \mathrm{mg} / \mathrm{L})+\mathrm{NAA}(0.5 \mathrm{mg} / \mathrm{L})$ along with CH $(400 \mathrm{mg} / \mathrm{L})$ which had given rise to 15 adventitious shoots whereas the nodal explants could induce only $4-5$ axillary shoots after 50 days after inoculation (Figure ld). The shoots elongated in the same medium were transferred to $1 / 2$ MS supplemented with IBA $(3.0 \mathrm{mg} / \mathrm{L}$ ) along with $200 \mathrm{mg} / \mathrm{L}$ activated charcoal (Figure 6c). A maximum of $45 \%$ of the plants produced well developed roots in half strength MS supplemented with $2 \mathrm{mg} / \mathrm{IBA}$. A similar procedure was reported by Srinidhi et al., (2008). The rooted plantlets were transplanted into polybags containing soil, sand and vermiculite and maintained in greenhouse (Figure 7).

\section{CONCLUSION}

In order to achieve the intended goal of large scale plant propagation of clonal plants, a minimum contamination, maximum shoot multiplication and successful plant
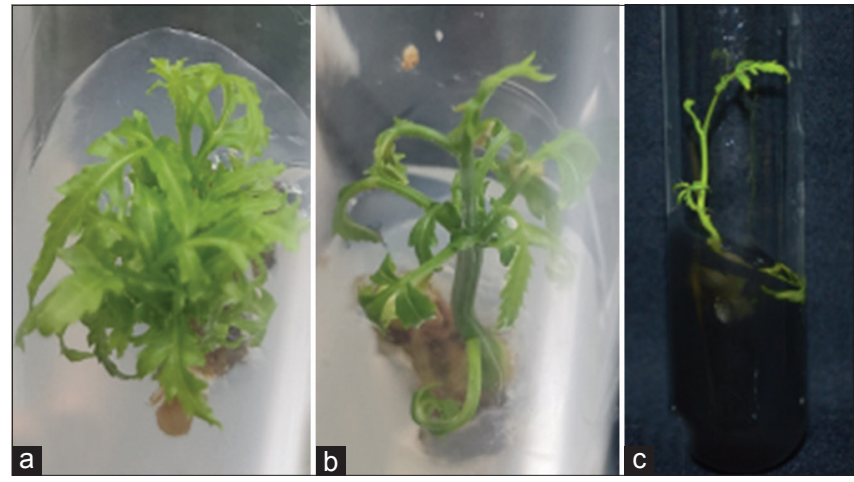

Figure 6: Shoot proliferation and rooting. (a) Multiple shoot induction from cotyledonary explants on multiple shoot induction medium, (b) Shoot elongation from cotyledons, (c) Elongated shoots kept for in vitro rooting media

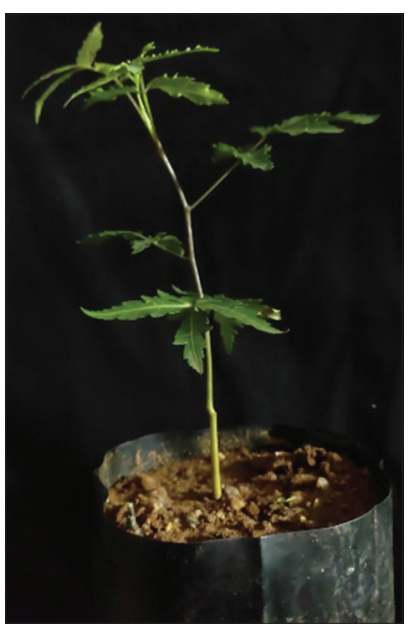

Figure 7: Acclimatized plantlet in polybag

establishment protocol is essential. The nodal explants though producing axillary shoots, inborn fungal and bacterial infection in establishment, low multiplication and poor rooting due to juvenility issues are hampering the use of nodal plants for large scale propagation. Even though somatic embryogenesis produced more number of somatic embryos per explant (24.97) within a short time (30-45 days), when compared to the other two explants, the conversion ratio was not found to be satisfactory. The de-embryonated cotyledons registered higher regeneration potential, responded well and produced more 
number of shoots on sub culturing (15) and subsequently be rooted in large number compared to other two explants, hence could be exploited in micro propagation of neem.

\section{ACKNOWLEDGEMENT}

We acknowledge the financial support in the form of fellowship provided by the Department of Biotechnology (DBT). No. BT/ HRD/01/011).

\section{REFERENCES}

Akula, C., Akula, A., \& Drew, R. (2003). Somatic embryogenesis in clonal neem, Azadirachta indica A. Juss. and analysis for in vitro azadirachtin production. In vitro Cellular \& Developmental Biology-Plant, 39(3), 304-310. https://doi.org/10.1079/IVP2003415

Arora, K., Sharma, M., Srivastava, J., Ranade, S., \& Sharma, A. (2010). Rapid in vitro cloning of a 40-year-old tree of Azadirachta indica A. Juss.(Neem) employing nodal stem segments. Agroforestry Systems, 78(1), 53. https://doi.org/10.1007/s10457-009-9230-1

Chaturvedi, R., Razdan, M., \& Bhojwani, S. (2004). In vitro clonal propagation of an adult tree of neem (Azadirachta indica A. Juss.) by forced axillary branching. Plant Science, 166(2), 501-506. https://doi.org/10.1016/j. plantsci.2003.10.021

Chaturvedi, R., Razdan, M., \& Bhojwani, S. (2004). In vitro morphogenesis in zygotic embryo cultures of neem (Azadirachta indica A. Juss.). Plant Cell Reports, 22(11), 801-809. https://doi.org/10.1007/s00299004-0768-0

Chowdhury, S., Basu, A., \& Kundu, S. (2014). A new high-frequency Agrobacterium-mediated transformation technique for Sesamum indicum L. using de-embryonated cotyledon as explant. Protoplasma, 251(5), 1175-1190. https://doi.org/10.1007/ s00709-014-0625-0

Deb, C. R. (2001). Somatic embryogenesis and plantlet regeneration of Melia azedarach L (Ghora Neem) from cotyledonary segments. Journal of Plant Biochemistry and Biotechnology, 10(1), 63-65. https:// doi.org/10.1007/BF03263110

Detrez, C., Ndiaye, S., \& Dreyfus, B. (1994). In vitro regeneration of the tropical multipurpose leguminous tree Sesbania grandiflora from cotyledon explants. Plant cell reports, 14(2), 87-93. https://doi. org/10.1007/BF00233767

Gairi, A., \& Rashid, A. (2005). Direct differentiation of somatic embryos on cotyledons of Azadirachta indica. Biologia Plantarum, 49(2), 169-173. https://doi.org/10.1007/s10535-005-0173-8

Gehlot, A., Gupta, R. K., Tripathi, A., Arya, I. D., \& Arya, S. (2014). Vegetative propagation of Azadirachta indica: effect of auxin and rooting media on adventitious root induction in mini-cuttings. Advances in Forestry Science, 1(1), 1-9. https://doi.org/10.34062/afs.v1i1.1357

Houllou, L. M., Souza, R. A. d., Santos, E. C. P. d., Silva, J. J. P. d., Barbosa, M. R., Sauvé, J. P. G., \& Harand, W. (2015). Clonal propagation of neem (Azadirachta indica A. Juss.) via direct and indirect in vitro regeneration. Revista Árvore, 39, 439-445. https:// doi.org/10.1590/0100-67622015000300004

Kong, D. M., Preece, J. E., \& Shen, H. L. (2012). Somatic embryogenesis in immature cotyledons of Manchurian ash (Fraxinus mandshurica Rupr.). Plant Cell, Tissue and Organ Culture (PCTOC), 108(3), 485-492. https://doi.org/10.1007/s11240-011-0062-0

Murthy, B., \& Saxena, P. K. (1998). Somatic embryogenesis and plant regeneration of neem (Azadirachta indica A. Juss.). Plant Cell Reports, 17(6), 469-475. https://doi.org/10.1007/s002990050427

Parveen, S., \& Shahzad, A. (2014). Encapsulation of nodal segments of Cassia angustifolia Vahl. for short-term storage and germplasm exchange. Acta Physiologiae Plantarum, 36(3), 635-640. https://doi. org/10.1007/s11738-013-1441-4

Quraishi, A., Koche, V., Sharma, P., \& Mishra, S. (2004). In vitro clonal propagation of neem (Azadirachta indica). Plant Cell, Tissue and Organ Culture, 78(3), 281-284. https://doi. org/10.1023/B: TICU.0000025647.58548.3d

Rangaswamy, N. S\& Promila (1972). Morphogenesis of the adult embryo of Azadirachta indica A. Juss. Zeitschrift für Pflanzenphysiologie, 67(4), 377-379. https://doi.org/10.1016/S0044-328X(72)80101-6

Rathore, J. S., Rai, M. K., \& Shekhawat, N. S. (2012). Induction of somatic embryogenesis in gum arabic tree [Acacia senegal (L.) Willd.]. Physiology and Molecular Biology of Plants, 18(4), 387-392. https://doi.org/10.1007\%2Fs12298-012-0130-x

Rout, G. R. (2005). In vitro somatic embryogenesis in callus cultures of Azadirachta indica A. Juss. - a multipurpose tree. Journal of Forest Research, 10(4), 263-267. https://doi.org/10.1007/s10310-004-0130-y

Salvi, N. D., Singh, H., Tivarekar, S., \& Eapen, S. (2001). Plant regeneration from different explants of neem. Plant Cell, Tissue and Organ Culture, 65(2), 159-162. https://doi.org/10.1023/A:1010672809141

Sezgin, M., \& Dumanoğlu, H. (2014). Somatic embryogenesis and plant regeneration from immature cotyledons of European chestnut (Castanea sativa Mill.). In Vitro Cellular \& Developmental BiologyPlant, 50(1), 58-68. https://doi.org/10.1007/s11627-013-9548-2

Shekhawat, G., Mathur, S., \& Batra, A. (2009). Role of phytohormones and nitrogen in somatic embryogenesis induction in cell culture derived from leaflets of Azadirachta indica. Biologia Plantarum, 53(4), 707. https://doi.org/10.1007/s10535-009-0127-7

Shrikhande, M., Thengane, S., \& Mascarenhas, A. (1993). Somatic embryogenesis and plant regeneration inAzadirachta indica A. Juss. In vitro Cellular \& Developmental Biology-Plant, 29(1), 38-42. https:// doi.org/10.1007/BF02632237

Singh, M., \& Chaturvedi, R. (2009). An efficient protocol for cyclic somatic embryogenesis in Neem (Azadirachta indica A. Juss). Proceedings of World Academy of Science Engineering and Technology. https:// doi.org/10.5281/zenodo.1079470

Sinha, R. K., \& Mallick, R. (1993). Regeneration and multiplication of shoot in Albizia falcataria. Plant Cell, Tissue and Organ Culture, 32(2), 259261. https://doi.org/10.1007/BF00029851

Srinidhi, H., Gill, R., \& Sidhu, D. (2008). Micropropagation of adult and juvenile neem (Azadirachta indica A. Juss). Journal of Crop Improvement, 21(2), 221-232. https://doi.org/10.1080/15427520701885790

Srivastava, V., \& Chaturvedi, R. (2018). Somatic Embryogenesis in Neem. Step Wise Protocols for Somatic Embryogenesis of Important Woody Plants, 369-386. https://doi.org/10.1007/9783-319-79087-9 27

Su, W. W., Hwang, W.-I., Kim, S. Y., \& Sagawa, Y. (1997). Induction of somatic embryogenesis in Azadirachta indica. Plant cell, tissue and organ culture, 50(2), 91-95. https://doi.org/10.1023/A:1005891113815

Subapriya, R., \& Nagini, S. (2005). Medicinal properties of neem leaves: a review. Current MedicinalChemistry-Anti-CancerAgents, 5(2)149-156. https://doi.org/doi.org/10.2174/1568011053174828

Thengane, S., Joshi, M., \& Mascarenhas, A. (1995). Somatic embryogenesis in neem (Azadirachta indica). In Somatic embryogenesis in woody plants (pp. 357-374). Springer. https://doi.org/10.1007/978-94-0110491-3_20 